\title{
Chronic disease self-management within the monthly benefit cycle of the Supplemental Nutrition Assistance Program
}

\author{
Eliza Whiteman Kinsey ${ }^{1, *}$, Roxanne Dupuis ${ }^{2}$, Megan Oberle ${ }^{3,4,5}$, \\ Carolyn C Cannuscio ${ }^{4,5}$ and Amy Hillier ${ }^{6}$ \\ 'Department of Epidemiology, Mailman School of Public Health, Columbia University, 722 West 168th Street, \\ New York, NY 10032, USA: ${ }^{2}$ Department of Social and Behavioral Sciences, Harvard T.H. Chan School of Public \\ Health, Boston, MA, USA: ${ }^{3}$ Division of Endocrinology and Diabetes, Department of Pediatrics, University of Minnesota \\ Medical School, Minneapolis, MN, USA: ${ }^{4}$ University of Pennsylvania Leonard Davis Institute of Health Economics, \\ Philadelphia, PA, USA: ${ }^{5}$ Department of Family Medicine and Community Health, University of Pennsylvania Perelman \\ School of Medicine, Philadelphia, PA, USA: ${ }^{\circ}$ School of Social Policy and Practice, University of Pennsylvania, \\ Philadelphia, PA, USA
}

Submitted 17 October 2018: Final revision received 12 February 2019: Accepted 27 February 2019: First published online 20 May 2019

\begin{abstract}
Objective: The present study explored chronic disease management over the monthly benefit cycle among primary food shoppers from households receiving Supplemental Nutrition Assistance Program (SNAP) benefits in Philadelphia, PA, USA.

Design: In-depth interviews, participant observation and surveys were conducted with the primary food shopper of SNAP households.

Setting: Interviews and surveys were conducted in a clinical setting at Children's Hospital of Philadelphia, at participants' homes, and in food procurement settings including grocery stores, food pantries and soup kitchens.

Participants: Eighteen adults who received SNAP; five with a diet-related chronic condition, five managing the chronic condition of a family member and thirteen with overweight or obesity.

Results: All households had at least one member with a chronic disease or condition. Households reported that the dietary demands of managing chronic illnesses were expensive and mentally taxing. Food and financial shortfalls at the end of the benefit cycle, as well as reliance on charitable food assistance programmes, often had negative impacts on chronic disease self-management.

Conclusions: Drawing from nearly $50 \mathrm{~h}$ of in-depth qualitative interviews with SNAP participants, the study highlights the dual cognitive burden of poverty and chronic disease and elucidates the particular challenges of food procurement and maintenance of diet quality throughout the benefit month faced by SNAP households with diet-related chronic diseases. Interventions targeted at reducing the cost of medically appropriate, healthy foods may help to improve chronic disease self-management within SNAP populations.
\end{abstract}

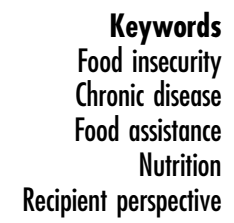

Food insecurity

Chronic disease

Nutrition

Recipient perspective
Food insecurity affects more than 680 million people across the world $^{(1)}$, with serious implications for many chronic conditions, including diabetes and obesity. In the USA, $11.8 \%$ of households are food insecure. The largest federal programme targeted at alleviating food insecurity is the Supplemental Nutrition Assistance Program (SNAP; formerly Food Stamps), an income-eligible entitlement programme used by one in seven US residents. Recent scholarship on the monthly SNAP benefit distribution schedule has found that longer duration from SNAP distribution is associated with poorer diet quality, energy restriction and higher likelihood of skipping meals ${ }^{(2-7)}$, all of which can have detrimental impacts on diet-related chronic diseases. Additionally, poverty and food insecurity pose significant barriers to proper self-management of chronic disease $^{(8)}$. Chronic disease self-management has been shown to reduce symptoms from chronic conditions, such as pain and fatigue, and reduce emergency room and 
outpatient medical visits among chronically ill populations. Effective self-management includes a medically recommended diet, appropriate exercise and use of medications, communication with family and medical providers, and awareness of treatment options ${ }^{(9,10)}$.

The associations between income, food insecurity and chronic disease morbidity and mortality have been well documented. In the USA, overall chronic disease rates are higher among households with annual income below \$US $35000^{(11)}$. Compared with an adult with no chronic conditions, an individual's odds of food insecurity increases along with the number of chronic conditions he/she has ${ }^{(12)}$. Food insecurity has been associated with poorer self-rated health and higher risk of hypertension, hyperlipidaemia, osteoporosis, diabetes mellitus, CVD and obesity ${ }^{(13-19)}$. Studies have shown food insecurity is adversely associated with health behaviours, including poorer LDLcholesterol control ${ }^{(20)}$, increased odds of HIV risk behaviours $^{(21-23)}$, poorer adherence to antiretroviral therapy and self-care among people with $\mathrm{HIV}^{(24-26)}$, and cost-related medication underuse among those who are chronically ill, especially among individuals who are Hispanic, Black or suffer from multiple chronic conditions ${ }^{(27)}$. Among SNAP recipients, CVD mortality rates are higher for non-Hispanic White and non-Hispanic Black individuals compared with both income-eligible and higher-income non-SNAP participants ${ }^{(28)}$. It has also been found that SNAP participants across all races/ethnicities have higher diabetes mortality compared with non-participants ${ }^{(28)}$.

Diet-related chronic disease self-management and outcomes among SNAP participants are critically understudied, particularly in light of the lower overall diet quality found among the SNAP population compared with nonparticipants ${ }^{(29)}$. Most of the existing SNAP cycle research has used large administrative data sets to quantify the effects of the monthly benefit cycle. The present mixedmethods study adds to the literature by using both survey data and in-depth qualitative inquiry to allow SNAP recipients to express in their own voice the particular challenges of chronic disease management within the context of SNAP benefit receipt and the volatility of the monthly SNAP benefit cycle. The qualitative approach in our study enables a richer, exploratory investigation of the experience of the SNAP cycle and provides the possibility of a wider range of participant responses than do closed-ended quantitative methodologies.

\section{Methods}

The current paper presents data from a prospective, mixedmethods study following two sequential cohorts of adult SNAP recipients ( $n$ 18) in Philadelphia, PA, USA, between 2016 and 2017. We recruited participants through word-ofmouth, with the assistance of several non-profit agencies in the Philadelphia area, and in-person at Children's Hospital of Philadelphia outpatient clinics. The first cohort was assembled for a clinical study; the second cohort was intended to augment the first.

Eligibility for the study required that participants were the primary food shopper for their household, at least 18 years of age and currently receiving SNAP benefits. For the first cohort, study participants ( $n$ 12) were food insecure, overweight or obese $\left(B M I=25 \cdot 0-39 \cdot 9 \mathrm{~kg} / \mathrm{m}^{2}\right)$ African-American mothers of young children. For the second cohort, we used purposive sampling to diversify the sample ( $n$ 6) to be more reflective of the SNAP population in Philadelphia. This sample included adults without children, seniors and people with disabilities, as well as participants of other racial and ethnic backgrounds. Across both phases of the study, we screened ninety-one people, of whom eighteen were eligible and consented to participate in the study.

Participation in both study cohorts lasted for one month and included a screening assessment at recruitment, followed by three study visits: one each at the beginning, middle and end of the SNAP month. Screening included an eligibility questionnaire and the US Household Food Security Module ${ }^{(30)}$. Study visits took place both in a clinical setting (cohort 1) and at locations selected by the participants where they either prepared or acquired food (cohort 2). Visit locations for cohort 2 included participant homes, grocery stores, food pantries and soup kitchens. Visits included surveys collected using REDCap, a secure online survey and data management tool ${ }^{(31)}$, and semi-structured interviews that were audio-recorded and transcribed verbatim. The surveys covered six main topics: (i) income and expenses; (ii) management of household finances; (iii) food shopping behaviours and attitudes; (iv) SNAP use patterns; (v) opinions about SNAP; and (vi) selfreported health. Interviews were largely open-ended and participant-guided with the interviewer using questions loosely adapted from the SNAP Food Security In-Depth Interview Study to prompt participants as needed ${ }^{(32)}$. The range of interview topics was determined by the research team after review of the literature and the open-ended interview guide was piloted prior to data collection. Topics covered included: (i) experience of the SNAP cycle; (ii) coping strategies for managing SNAP and food insecurity; (iii) food shopping and meal patterns; (iv) use of the charitable food sector; (v) financial volatility; (vi) social networks; and (vii) personal health experiences, among others. The interviews were typically 30-90 min in length.

\section{Analysis of interview transcripts and surveys}

Survey data were analysed using the statistical software package Stata version 14.2. For the semi-structured interviews, two members of the research team performed a line-byline reading of a subset of transcripts to identify recurrent concepts. The transcripts were coded by both researchers using NVivo version 11 qualitative data analysis software, with 93.3\% agreement. Consistent with the COREQ (Consolidated Criteria for Reporting Qualitative Research) 
Table 1 Sample characteristics of both study cohorts: adult primary food shoppers from households receiving Supplemental Nutrition Assistance Program benefits ( $n$ 18), Philadelphia, PA, USA, 2016-2017

\begin{tabular}{|c|c|}
\hline Characteristic & Mean or $(\%)$ \\
\hline \multicolumn{2}{|c|}{ Individual characteristics of primary study participant } \\
\hline Age (years), mean & $36 \cdot 5$ \\
\hline \multicolumn{2}{|l|}{ Gender (\%) } \\
\hline Female & 88.9 \\
\hline Male & $11 \cdot 1$ \\
\hline \multicolumn{2}{|l|}{ Race/ethnicity (\%) } \\
\hline White & $5 \cdot 6$ \\
\hline Black & $61 \cdot 1$ \\
\hline Latino/Hispanic & $16 \cdot 7$ \\
\hline Multi-racial or Other & $16 \cdot 7$ \\
\hline \multicolumn{2}{|l|}{ Marital status (\%) } \\
\hline Married & $16 \cdot 7$ \\
\hline Single & $66 \cdot 7$ \\
\hline Divorced/separated & $16 \cdot 7$ \\
\hline \multicolumn{2}{|l|}{ Employment (\%) } \\
\hline Part-time & 33.3 \\
\hline Full-time & $16 \cdot 7$ \\
\hline Not currently working* & $50 \cdot 0$ \\
\hline \multicolumn{2}{|l|}{ Education (\%) } \\
\hline Less than high school & $5 \cdot 6$ \\
\hline High-school degree & $22 \cdot 2$ \\
\hline Some college & 44.4 \\
\hline College degree or above & $27 \cdot 8$ \\
\hline \multicolumn{2}{|l|}{ Household characteristics } \\
\hline \multicolumn{2}{|l|}{ Household composition } \\
\hline Household size, mean & $3 \cdot 3$ \\
\hline Single-adult households (\%) & $16 \cdot 7$ \\
\hline $\begin{array}{l}\text { Single elderly individual households } \\
\quad(\text { aged } \geq 65 \text { years; \%) }\end{array}$ & $5 \cdot 6$ \\
\hline Households with elderly individuals (\%) & $11 \cdot 1$ \\
\hline Households with children (\%) & $77 \cdot 8$ \\
\hline $\begin{array}{l}\text { Households with school-age children } \\
\text { (aged 5-17 years; \%) }\end{array}$ & $61 \cdot 1$ \\
\hline $\begin{array}{l}\text { Households with individuals with } \\
\text { diet-related chronic condition(s) (\%) }\end{array}$ & $100 \cdot 0$ \\
\hline Monthly income† (\$US), mean & 1514.61 \\
\hline Monthly expenses $\ddagger$ (\$US), mean & 1112.53 \\
\hline Monthly SNAP benefit (\$US), mean & $241 \cdot 22$ \\
\hline Visited food pantry in last year (\%) & $50 \cdot 0$ \\
\hline Large/unusual expense in last month (\%) & 33.3 \\
\hline Has a drivable motor vehicle (\%) & $55 \cdot 6$ \\
\hline \multicolumn{2}{|l|}{ Household food security status (\%) } \\
\hline Food secure & $5 \cdot 6$ \\
\hline Low food security & 38.9 \\
\hline Very low food security & $55 \cdot 6$ \\
\hline
\end{tabular}

*This includes individuals who do not work, are currently searching for work, unable to work because of a disability and unable to work because of a felony conviction. †Self-reported monthly income from wages, tips, unemployment payments, disability payments, social security, retirement payments, cash welfare, child support (court mandated and informal), Subsidized Child Care Program, loans, gifts and prizes.

¥Self-reported monthly expenses from rent/mortgage, homeowner's/renter's insurance, electricity, heating fuels, transportation (car payments, gas, parking tickets, public transit), telephone, cable, Internet, child care, adult care, health insurance, medical co-pays, uninsured medical bills and student loans.

guidelines for qualitative research, the researchers summarized the findings by code and these summaries were used to guide group discussion and iterative interpretation of the data by the study team to identify cross-cutting themes that integrated findings across codes and across the two study cohorts $^{(33-36)}$.

The study was approved by the University of Pennsylvania and Children's Hospital of Philadelphia Institutional Review Boards.

\section{Results}

Table 1 describes the characteristics of the eighteen participants across both cohorts. The mean age was 37 years and the majority ( $89 \%$ ) of participants were female. Among the sample, $56 \%$ reported very low household food security, meaning that at times during the past year, one or more household members cut or skipped meals and food consumption declined because they lacked the resources with which to procure food. Nearly two-thirds of participants $(61 \%)$ reported having or caring for a household member with a diet-related chronic disease. When including overweight/obesity as a chronic condition, this was $100 \%$.

While participants were not recruited based on their experiences managing chronic diseases, all of them either had a chronic disease or were managing one within their family. The reported chronic conditions included ones either explicitly diet-related or those with serious dietary implications: diabetes (types 1 and 2), Crohn's disease, CVD, phenylketonuria (PKU), HIV, Alagille syndrome (a rare genetic disorder), hypertension, overweight/ obesity (all participants in cohort 1 and $50 \%$ of cohort 2), lactose intolerance, severe food allergies, hypothyroidism, high cholesterol and pancreatitis (Table 2). Stemming from these chronic illnesses, participants reported during the interviews a wide range of physical and emotional side-effects and co-morbidities such as pain, neuropathy, blindness, fatigue, depression and anxiety, hair loss, rapid weight loss, brain damage, liver and kidney problems, anaphylaxis, insomnia, skin rashes, fear and loneliness.

\section{Diet management during the SNAP cycle}

An essential component of self-managing chronic diseases described by participants was a near-constant vigilance and monitoring. With respect to diet, this often took the form of regular consumption or avoidance of certain foods (e.g. sugar, salt, nuts, dairy, fruits and vegetables), as well as monitoring of nutrient intake (e.g. counting carbohydrates) and tracking health indicators (e.g. checking blood sugar levels). For participants with types 1 and 2 diabetes, sugar-free and low-carbohydrate food products were important staple items in their diet. As Eduardo*, who has type 1 diabetes, explained:

'I've just gotta be aware of my carbs, like ... I gotta figure out how many carbs is in there. Like if I get a half a banana would be, I think, maybe 50 carbs. I don't know. But there are some bananas that are sweeter than others.'

Latasha and Candice, both of whose children have wheat allergies, discussed searching for and purchasing

*All participant names have been changed to protect confidentiality. 
Table 2 Diet-related chronic diseases, management and consequences within the pooled study sample of adult primary food shoppers from households receiving Supplemental Nutrition Assistance Program benefits ( $n$ 18), Philadelphia, PA, USA, 2016-2017

\begin{tabular}{|c|c|c|c|c|c|}
\hline Participant & Chronic disease(s) & $\begin{array}{l}\text { Symptoms of } \\
\text { disease }\end{array}$ & $\begin{array}{l}\text { Dietary } \\
\text { specifications of } \\
\text { disease }\end{array}$ & Disease coping strategies & $\begin{array}{l}\text { Unresolved } \\
\text { challenges }\end{array}$ \\
\hline $\begin{array}{l}\text { Eduardo, 57-year-old } \\
\text { divorced Puerto Rican } \\
\text { man, former nurse, } \\
\text { lives alone }\end{array}$ & $\begin{array}{l}\text { - Type } 1 \text { diabetes } \\
\text { - CVD } \\
\text { - Hypertension }\end{array}$ & $\begin{array}{l}\text { - Neuropathy } \\
\text { - Blindness }\end{array}$ & $\begin{array}{l}\text { Low-sugar, low- } \\
\text { salt, high intake } \\
\text { of fruits and } \\
\text { vegetables, } \\
\text { regular caloric } \\
\text { consumption } \\
\text { to avoid } \\
\text { hypoglycaemia }\end{array}$ & $\begin{array}{l}\text { Food pantry, home health } \\
\text { aides, medical } \\
\text { professionals, regular self- } \\
\text { monitoring, diet trade-offs } \\
\text { (i.e. calories over } \\
\text { nutritional quality) }\end{array}$ & $\begin{array}{l}\text { - Difficulty } \\
\text { controlling } \\
\text { blood sugar } \\
\text { - Impaired } \\
\text { mobility } \\
\text { - Depression, } \\
\text { loneliness }\end{array}$ \\
\hline $\begin{array}{l}\text { Scott, } 31 \text {-year-old single } \\
\text { Black man, formerly } \\
\text { incarcerated, currently } \\
\text { unemployed and living } \\
\text { with his mother }\end{array}$ & $\begin{array}{l}\text { - HIV } \\
\text { - High-risk } \\
\text { hypertension }\end{array}$ & $\begin{array}{l}\text { - } \text { Fatigue } \\
\text { - Rapid } \\
\text { weight loss } \\
\text { - Kidney } \\
\text { problems } \\
\text { - Insomnia }\end{array}$ & $\begin{array}{l}\text { Low-sugar, } \\
\text { low-salt, extra } \\
\text { calories for } \\
\text { weight } \\
\text { management }\end{array}$ & $\begin{array}{l}\text { Food pantry, soup kitchen, } \\
\text { medical professionals, } \\
\text { HIV-specific resource } \\
\text { centre, diet trade-offs, } \\
\text { sharing food with } \\
\text { neighbours, lives with } \\
\text { mother }\end{array}$ & $\begin{array}{l}\text { - Rapid weight } \\
\text { loss } \\
\text { - Not taking } \\
\text { medications } \\
\text { - Very low food } \\
\text { security }\end{array}$ \\
\hline $\begin{array}{l}\text { Linda, 66-year-old single } \\
\text { White woman, former } \\
\text { social worker, lives } \\
\text { alone in subsidized } \\
\text { senior housing }\end{array}$ & $\begin{array}{l}\text { - Fibromyalgia } \\
\text { - Pre-diabetes } \\
\text { - Overweight }\end{array}$ & $\begin{array}{l}\text { - Pain } \\
\text { - Fatigue }\end{array}$ & $\begin{array}{l}\text { Low-sugar, } \\
\text { regular caloric } \\
\text { consumption } \\
\text { to avoid } \\
\text { hypoglycaemia }\end{array}$ & $\begin{array}{l}\text { Food pantry, senior meals } \\
\text { site, selling household } \\
\text { items, borrowing money, } \\
\text { skipping meals, diet } \\
\text { trade-offs }\end{array}$ & $\begin{array}{l}\text { - Not taking } \\
\text { medications } \\
\text { - Very low food } \\
\text { security }\end{array}$ \\
\hline $\begin{array}{l}\text { Carmen, 33-year-old } \\
\text { married mother of two, } \\
\text { born in Puerto Rico and } \\
\text { moved to Philadelphia } \\
\text { for her son's medical } \\
\text { care }\end{array}$ & $\begin{array}{l}\text { - Son: Alagille } \\
\text { syndrome (rare } \\
\text { genetic disorder that } \\
\text { affects the liver, } \\
\text { heart, kidneys, } \\
\text { skeleton and eyes) } \\
\text { - Overweight }\end{array}$ & $\begin{array}{l}\text { - Liver and } \\
\text { kidney } \\
\text { problems }\end{array}$ & $\begin{array}{l}\text { No gluten, avoid } \\
\text { certain fats, } \\
\text { low- } \\
\text { carbohydrate } \\
\text { diet for weight } \\
\text { loss }\end{array}$ & $\begin{array}{l}\text { Food pantry, medically } \\
\text { tailored meals service, } \\
\text { sharing food with friends }\end{array}$ & $\begin{array}{l}\text { - Meal service } \\
\text { ending } \\
\text { - Ongoing } \\
\text { health } \\
\text { complications }\end{array}$ \\
\hline $\begin{array}{l}\text { Tracie, 28-year-old single } \\
\text { Black mother of two, } \\
\text { works full-time and is a } \\
\text { student part-time, lives } \\
\text { with her mother and } \\
\text { brother }\end{array}$ & $\begin{array}{l}\text { - Lactose intolerance } \\
\text { - Mother: Crohn's } \\
\text { disease } \\
\text { - Overweight }\end{array}$ & - Diarrhoea & No dairy & $\begin{array}{l}\text { Borrowing money, childcare } \\
\text { support from friends and } \\
\text { family, lives with mother }\end{array}$ & - Overweight \\
\hline $\begin{array}{l}\text { Kayla, 25-year-old single } \\
\text { White-Hispanic woman, } \\
\text { formerly homeless, } \\
\text { currently living with her } \\
\text { great-grandmother }\end{array}$ & $\begin{array}{l}\text { - Phenylketonuria } \\
\text { - Bipolar disorder }\end{array}$ & $\begin{array}{l}\text { - Hair and } \\
\text { weight loss } \\
\text { - Skin rashes, } \\
\text { pallor } \\
\text { - Depression, } \\
\text { anxiety }\end{array}$ & Low-protein diet & $\begin{array}{l}\text { Soup kitchen, homeless- } \\
\text { specific resource centre, } \\
\text { borrowing money, informal } \\
\text { economy, diet trade-offs, } \\
\text { lives with great- } \\
\text { grandmother }\end{array}$ & $\begin{array}{l}\text { - Not adhering } \\
\text { to diet } \\
\text { - Not taking } \\
\text { medications }\end{array}$ \\
\hline $\begin{array}{l}\text { Candice, 39-year-old } \\
\text { married Black mother of } \\
\text { four, unemployed and in } \\
\text { school }\end{array}$ & $\begin{array}{l}\text { - Obesity } \\
\text { - Daughter: severe } \\
\text { food allergies } \\
\text { - Husband: cancer }\end{array}$ & - Anaphylaxis & $\begin{array}{l}\text { No wheat, nuts, } \\
\text { soya, coconut, } \\
\text { palm oil }\end{array}$ & $\begin{array}{l}\text { Borrowing food and money } \\
\text { from friends and family, } \\
\text { diet trade-offs, skipping } \\
\text { meals }\end{array}$ & $\begin{array}{l}\text { - Cannot } \\
\text { afford } \\
\text { allergen-safe } \\
\text { foods } \\
\text { - Obesity } \\
\text { - Unemployed } \\
\text { - Very low food } \\
\text { security }\end{array}$ \\
\hline $\begin{array}{l}\text { Latasha, 39-year-old } \\
\text { married Black mother of } \\
\text { six, unemployed, living } \\
\text { in unstable housing }\end{array}$ & $\begin{array}{l}\text { - Obesity } \\
\text { - Children: severe } \\
\text { food allergies, } \\
\text { asthma } \\
\text { - Husband: paranoid } \\
\text { schizophrenia }\end{array}$ & - Anaphylaxis & $\begin{array}{l}\text { No dairy, nuts, } \\
\text { soya, wheat, } \\
\text { fish }\end{array}$ & $\begin{array}{l}\text { Borrowing food and money } \\
\text { from friends and family, } \\
\text { diet trade-offs, skipping } \\
\text { meals }\end{array}$ & $\begin{array}{l}\text { - Cannot } \\
\text { afford } \\
\text { allergen-safe } \\
\text { foods } \\
\text { - Obesity } \\
\text { - Uncontrolled } \\
\text { asthma } \\
\text { - Unemployed } \\
\text { - Very low food } \\
\text { security }\end{array}$ \\
\hline $\begin{array}{l}\text { Taylor, 27-year-old single } \\
\text { Black mother of one, } \\
\text { works part-time, lives } \\
\text { with her mother }\end{array}$ & $\begin{array}{l}\text { - Overweight } \\
\text { - Daughter: food } \\
\text { allergies }\end{array}$ & - Anaphylaxis & $\begin{array}{l}\text { Unknown } \\
\text { allergens }\end{array}$ & $\begin{array}{l}\text { Borrowing food and money } \\
\text { from family }\end{array}$ & $\begin{array}{l}\text { - Unknown } \\
\text { allergens } \\
\text { - Overweight }\end{array}$ \\
\hline
\end{tabular}


gluten-free items. Based on inclusion criteria for the first study cohort, the majority of participants were overweight or obese and several were following specific diets to lose weight. For Kayla, who has PKU, a low-protein diet is critical for proper management of her illness. The range of dietary requirements represented across our study sample (Table 2) illustrates the heterogeneity of food needs between SNAP households.

Often specialized diets necessitated the purchase and preparation of different foods within households. During a home visit, Carmen opened her refrigerator to display the three kinds of milk she purchased to accommodate her family's different dietary needs: coconut milk for herself (as part of a weight-loss programme), almond milk for her children (for lactose intolerance) and regular milk for her husband. Carmen was also was on a highly restrictive low-carbohydrate diet for weight loss that required preparation of separate meals from those she made for the rest of her family. Latasha, who has six children, several of whom have different food allergies, struggles to keep up with the varied food items that are safe for each child.

The end-of-month period was highlighted by participants as being particularly difficult financially, which often had repercussions on diet and chronic disease management. The average SNAP benefit allotment per household within the sample was \$US 241 and despite techniques for budgeting SNAP resources, all participants reported that their SNAP ran out before benefits were renewed - typically between the second and third week of the cycle. Several participants noted skipping meals in the final weeks of the SNAP cycle, which sometimes resulted in low blood sugar. For Eduardo's diabetes management, the necessity of eating to avoid hypoglycaemic incidents was paramount, which included trying to keep snacks and juice on hand at all times. To do this, he relied on monthly trips to the food pantry. For Linda, who was pre-diabetic, keeping food in the house at all times was challenging, as her SNAP benefit was only \$US 16 per month, which meant that by the end of the month when she had no money left she resorted to creative strategies for obtaining food such as getting a slice of pizza on credit or having a yard sale with items from her apartment.

For a number of participants, the end-of-month period was also accompanied by less healthy eating patterns. Eduardo explained that a can of soup was his go-to meal when SNAP would run out:

'Chicken noodle. Yeah. Just 99 cents at ShopRite. The little can, Campbell? Yeah. Can of soup and bread. And you know like survive ... But then on the other hand my health is not surviving.'

Reliance on low-cost, high-sodium foods like canned soup at the end of the benefit month allowed Eduardo to feed himself, but was bad for his hypertension and deregulated his blood sugar levels.

\section{Key themes}

In addition to the overarching study topic of diet and chronic disease self-management during the SNAP cycle, participant interviews revealed four key themes: (i) cost of medically appropriate diets; (ii) interplay between health and financial instability; (iii) relationships with formal support systems; and (iv) constraints of depending on the charitable food sector.

\section{Cost of medically appropriate diets}

Despite high awareness of their dietary needs for disease management, participants recounted difficulty staying 'ondiet' because of limited financial resources. For example, Scott was suffering from rapid weight loss associated with HIV and had been advised by his nutritionist to eat more calories, which he feared was not affordable given his limited SNAP benefit and inconsistent cash income. He said:

'They want me to go on 3600 calories a day. That's a lot. And that's expensive, so I don't know how that can happen. ... They did not tell me how to pay for it, but they gave me a printout of what to buy. I'm like, who's gonna pay for that? That's not gonna happen.'

Scott felt that doctors and nutritionists he visited did not understand the realities of poverty or of depending on SNAP benefits to buy food and therefore did not make feasible suggestions for diet management.

Participants often talked about the extra expense of foods for specialized diets (e.g. almond milk, gluten-free products), compared with their regular alternatives. For some participants, spending more of their budget on food caused significant financial strain. Candice and Latasha, both of whom have children with severe food allergies, lamented the challenge of finding safe foods that were not too cost-prohibitive. In addition to reporting that they could not afford special foods for medical conditions, many participants expressed a feeling of being unable to buy 'healthy' foods like fruits and vegetables on a SNAP budget because those items cost more than less healthy, often highly processed options.

Another participant, Kayla, expressed frustration that she was not able to use her SNAP benefits to purchase the low-protein foods recommended for the management of her PKU because they are available only through online websites where SNAP cannot be used. As a result, she explained, she eats whatever foods she can, even if that means going off-diet, because she cannot afford to buy the medically tailored foods with cash:

'There's websites that I can order food from, special low-protein foods. It's just for people with my diet. But I can't afford it.'

For Kayla, dependence on SNAP and the long-term consumption of foods that are non-adherent to medical recommendations for her PKU have resulted in pallor, underweight and hair loss, and could result in brain damage in the long run. 


\section{Interplay between bealth and financial instability}

Living with a chronic disease was marked by a high degree of instability and unpredictability. Unexpected health complications were frequent, oftentimes imposing unanticipated expenses such as medical bills (e.g. uninsured ambulance rides) or special post-surgery foods. The unpredictable nature of chronic illness also made it difficult for participants to plan, travel or keep regular work. Linda, an older woman suffering from fibromyalgia, recounted frequently cancelling or rescheduling appointments because of flare-ups in her pain or fatigue:

'My fibromyalgia is really bad in the winter and my arthritis is really bad in the winter. I have about $50 \%$ less energy. So it's this unpredictability which is why I couldn't get up at seven o'clock in the morning and have to be at work at nine. I could never do it.'

The unpredictability of Linda's illness exacerbated her financial instability, as it made keeping regular commitments, such as a job, nearly impossible.

Participants often framed their experiences around life before and after the illness. Living with a chronic disease was frequently marked by a transition period and required adjustment to new routines. For some, this meant moving to a new city to access better medical care or social service resources. Participants suffering from physical impairment as a result of their chronic disease (e.g. blindness, difficulty walking) expressed missing the physical independence they used to have. These transitions, and sometimes drastic changes in lifestyle, caused many participants to feel lonely, frustrated and depressed.

Like Linda, four other participants had lost their jobs (27.8\%), either because their illness made working too challenging or because managing their child's illness caused them to miss too many days of work. As Carmen explained, she was forced to leave her job at a pharmacy after using all her vacation and sick days taking her child to the doctor. For Carmen, not only did managing her son's chronic disease cause her to lose her job, but she was also forced to file for bankruptcy to manage the medical bills. Several mothers in the study had children with severe asthma which, while not a diet-related chronic illness, posed significant financial challenges that impacted household food security. For example, Latasha was forced to resign from her nursing job after missing too many shifts due to her son's asthma resulting in emergency room visits. After losing her job, she fell behind on bills and the family was eventually evicted from their home. The time burden of managing chronic illness created financial instability in the lives of many participants, which only compounded the end-of-month deficits they experienced as part of the SNAP cycle.

Lastly, a number of participants, including Latasha, remarked on the psychological challenge of no longer being able to work; they missed the financial independence of having a full-time job, as well as the routine, social interactions and mental stimulation:
'So I wanna go back to work. I wanna live a normal life again. It felt really, really good doing it, getting up in the morning, going to go get hot tea and a bagel and going to work. That was - people need that.'

\section{Relationships with formal support systems}

To aid in chronic disease management and fill in the gaps throughout the SNAP benefit month, participants utilized a variety of local community organizations, resource centres and health-care experts. All participants consulted regularly with some form of medical or social service provider. Several participants had established strong relationships with more comprehensive community resource centres targeted at specific vulnerable populations. For example, Scott received a range of services from a local non-profit dedicated to serving the HIV-positive community, including medical care, food assistance, legal aid, post-incarceration resources and job training. For Kayla, who had formerly been homeless and frequently had unstable housing arrangements, a homeless resource centre was instrumental in her survival, providing not just meals, but clothing, body care supplies, health screenings and even a steady address at which she could receive her mail, which she needed to maintain her SNAP benefits. As she explained:

'This is my favourite place ... I'm not on the streets now, but I still come here ... They got personal care. They got [subway fares] for people who need it ... The lady who doesn't work here no more, she helped me apply to [community college]. They help you.'

Organizations such as these provided much needed instrumental support for the participants in our study.

A critical way that local social welfare resource providers supported participants was through individualized care. When Eduardo was struggling financially, his social worker came by his house with several bags of food and put his name on a waitlist for a health-focused food pantry. Linda, who lives alone and survives off her social security benefits, described how several times in the prior months she had run out of money before her benefits were renewed and had called the food pantry to reschedule her monthly visit so that she could go in for food a week earlier. Carmen, whose son is chronically ill, recounted how an employee at the medically tailored meals delivery programme she used pulled some strings to extend the service beyond the typical three-month period. Participants emphasized how critical the personalized attention they received was in helping them maintain a positive mental outlook, 'get back on their feet' and manage their chronic disease.

Constraints of depending on the charitable food sector In addition to receiving SNAP, more than half our participants frequented community food assistance facilities such as food pantries or congregate meal sites (e.g. soup kitchens, churches, senior centres). The usage patterns of community food assistance varied, with some participants 
incorporating these resources into their regular weekly or monthly food acquisition strategies, while others relied on these programmes particularly at the end of the month when SNAP had run out. Participants who used community food assistance felt these resources were critical in ensuring that they were able to eat in the final days and weeks of the benefit cycle. As one participant stated:

'[B]y the second week, almost close to the third, I run out. So then I have no choice but to come here or starve.'

Others described using food assistance resources regularly throughout the month, not just at the end, to stretch their SNAP benefits. Kayla, who had formerly been homeless, ate nearly daily - sometimes multiple meals per day - at local churches and homeless resource centres. She displayed an intimate knowledge of the free meal network in the city:

'We tend to go to all the places that they feed during the day, throughout the day. We know where to go on a Monday, where to go on a Tuesday. We know all the days of the week where to go.'

For many of the households who used community food assistance resources, these places were not just last resorts during an emergency, but rather had become regular components of their food procurement strategies.

While community food assistance facilities were vital resources in managing food insecurity throughout the benefit month, participants felt they did not always offer nutritionally adequate items, with serious implications for chronic disease management. During one of our visits together at a resource centre for the HIV-positive community, Scott complained that the food pantries he visited largely offered canned or processed foods which were high in sodium and did not meet the standards recommended to him by a nutritionist for management of his hypertension. Scott also recounted being offered cake for breakfast at a local soup kitchen, as well as fast-food vouchers and Hungry-Man ${ }^{\circledR}$ meals. Several participants felt that they had no choice but to eat the foods they were offered. As Kayla described of the meals she received at free meal sites:

'I have a genetic disorder called PKU, so I'm not supposed to eat meat. [If I eat it] my phenylalanine goes up, my levels, my blood. Little symptoms, little things start happening. Then long-term is brain damage ... I'm going to eat it anyway, because I'm hungry. It's really all that I have.'

By virtue of depending on these community resources as regular and vital sources of their monthly food supply, participants often lacked control over the foods they were eating.

Despite noted inadequacies, charitable food assistance sites often played an integral role in the chronic disease management of participants. Several participants regularly visited one food pantry in North Philadelphia that followed nutritional guidelines for the foods it offered (often called a 'Green Light Pantry'), including an emphasis on fresh fruits and vegetables, whole grains and low-sodium items. Carmen, who visited this pantry each month, was grateful that the food offerings aligned with the dietary requirements for her son's chronic illness. When grocery shopping, Carmen often selected the same brands or products at the store, demonstrating her approval of the foods offered at the food pantry.

\section{Discussion}

To our knowledge, the present study is the first to explore self-management of diet-related chronic disease within the context of SNAP benefit receipt and the monthly SNAP cycle. Drawing from nearly $50 \mathrm{~h}$ of in-depth qualitative interviews with SNAP participants, the study highlights the dual cognitive burden of poverty and chronic disease and elucidates the particular challenges of food procurement and maintenance of diet quality throughout the benefit month faced by SNAP households with diet-related chronic diseases. The emergent themes from this research point to the two key issues discussed below: (i) affording the dietary needs of chronic disease with SNAP; and (ii) the importance and limitations of formalized care in managing chronic disease within low-income populations. Table 3 also provides policy recommendations by emergent theme, which will be further discussed below.

\section{Affording chronic disease dietary needs with SNAP}

A key finding from the present study is the inadequacy of SNAP benefits, either in lasting for the full monthly benefit cycle or for routinely purchasing healthy foods. While consistent with prior SNAP literature ${ }^{(3,4,6,29,37)}$, our study highlights the particular challenges faced by households managing diet-related chronic diseases as a result of the insufficiency of SNAP benefits. In our interviews, participants highlighted multiple ways in which relying on SNAP constrained or challenged their ability to purchase foods that supported healthy disease management, including not being able to afford more expensive, specialized diet foods (e.g. gluten-free alternatives) and struggling to purchase adequate calories for weight or blood sugar maintenance. Running out of SNAP at the end of the month also impacted self-management of chronic disease, as the emphasis in those final weeks of the benefit month was frequently on sufficient consumption, rather than the healthfulness of foods consumed, which highlights the degree to which participants were surviving, and not thriving, in times of financial shortfall. This finding within our participants aligns with a recent study by Seligman and colleagues demonstrating that low-income patients admitted to hospital for hypoglycaemia increased by more than 
Table 3 Themes, sample quotes and policy recommendations from in-depth qualitative interviews with adult primary food shoppers from households receiving Supplemental Nutrition Assistance Program (SNAP) benefits ( $n$ 18), Philadelphia, PA, USA, 2016-2017

\begin{tabular}{|c|c|c|c|}
\hline & Emergent themes & Sample quotes & Policy recommendations \\
\hline \multicolumn{4}{|l|}{ Primary study area } \\
\hline $\begin{array}{l}\text { Diet management } \\
\text { over the SNAP } \\
\text { cycle }\end{array}$ & $\begin{array}{l}\text { - Different foods/diets for } \\
\text { different family members } \\
\text { - End-of-month foods } \\
\text { especially bad for } \\
\text { chronic disease } \\
\text { - Constant vigilance }\end{array}$ & $\begin{array}{l}\text { 'And my son, he has multiple food allergies, so it's } \\
\text { like Whole Foods stores would be a great place } \\
\text { for him and it's, they're expensive. I go in there, } \\
\text { we probably will be struggling to eat for the rest } \\
\text { of the month.' }\end{array}$ & $\begin{array}{l}\text { 1. Provide larger SNAP } \\
\text { benefits } \\
\text { 2. Increase frequency of benefit } \\
\text { distribution }\end{array}$ \\
\hline \multicolumn{4}{|l|}{ Key themes } \\
\hline $\begin{array}{l}\text { Cost of medically } \\
\text { appropriate diets }\end{array}$ & $\begin{array}{l}\text { - Too expensive to eat } \\
\text { recommended calories } \\
\text { - Medically appropriate } \\
\text { foods are expensive } \\
\text { - Eat unhealthy foods to } \\
\text { survive } \\
\text { - Difficulty of staying } \\
\text { 'on-diet' }\end{array}$ & $\begin{array}{l}\text { 'I don't think a lot of people understand living on } \\
\text { benefits, so I don't think they would know what } \\
\text { to recommend.' } \\
\text { 'She has a lot of allergies, but now we think that's } \\
\text { wheat and everything I look at, it has wheat, } \\
\text { something like that. So l'm trying to figure out a } \\
\text { way to get food for her and the gluten-free things } \\
\text { which are so expensive.' }\end{array}$ & $\begin{array}{l}\text { 1. Improve access to healthy } \\
\text { foods, including: } \\
\text { a. Healthy food subsidy and } \\
\text { voucher programmes } \\
\text { b. Vegetable prescription } \\
\text { programmes } \\
\text { c. Insurance coverage for } \\
\text { food } \\
\text { d. Workplace wellness } \\
\text { benefits }\end{array}$ \\
\hline $\begin{array}{l}\text { Interplay between } \\
\text { health and } \\
\text { financial instability }\end{array}$ & $\begin{array}{l}\text { - Unpredictability of chronic } \\
\text { disease } \\
\text { - Unable to work because } \\
\text { of physical side-effects } \\
\text { of chronic disease } \\
\text { - Transition to life with } \\
\text { chronic disease }\end{array}$ & $\begin{array}{l}\text { 'My fibromyalgia is really bad in the winter and my } \\
\text { arthritis is really bad in the winter. I have about } \\
50 \% \text { less energy. So it's this unpredictability } \\
\text { which is why I couldn't get up at seven o'clock in } \\
\text { the morning and have to be at work at nine. } \\
\text { I could never do it. I have to cancel stuff all the } \\
\text { time, especially in the winter. I'll plan things and } \\
\text { then I wake up that morning and I feel like shit. } \\
\text { You just can't do it.' }\end{array}$ & $\begin{array}{l}\text { 1. Increase benefit size } \\
\text { 2. Provide structural support for } \\
\text { people receiving disability, } \\
\text { including: } \\
\text { a. Removing administrative } \\
\text { hurdles for benefits } \\
\text { application and } \\
\text { recertification } \\
\text { b. Improved transportation } \\
\text { services for food } \\
\text { shopping and medical } \\
\text { appointments }\end{array}$ \\
\hline $\begin{array}{l}\text { Relationships with } \\
\text { formal support } \\
\text { systems }\end{array}$ & $\begin{array}{l}\text { - Using emergency } \\
\text { resources at the end of } \\
\text { the month when SNAP } \\
\text { runs out } \\
\text { - Importance of } \\
\text { individualized care from } \\
\text { formal support systems }\end{array}$ & $\begin{array}{l}\text { 'Matter of fact, my social worker was the one who } \\
\text { signed me up for it. I didn't even know. But one } \\
\text { time she came to visit me here and she noticed } \\
\text { that my food stamps, they failed to send me my } \\
\text { food stamps. So she came here with a } \\
\text { gentleman and she brought me three bags from } \\
\text { a pantry and l'm oh, God bless you.' } \\
\text { 'I had to give up my car. Couldn't drive anymore. } \\
\text { And that's what got me depressed and } \\
\text { everything, too. I was an active person, doing a } \\
\text { lot things. And now, all of sudden - I mean, I got } \\
\text { to be grateful, right, that people will come over } \\
\text { and help me out, but I wanna do more. I wanna } \\
\text { be able to do it myself.' }\end{array}$ & $\begin{array}{l}\text { 1. Perform food insecurity } \\
\text { screenings in clinical } \\
\text { settings } \\
\text { 2. Better integrate health and } \\
\text { social services including co- } \\
\text { location and referrals }\end{array}$ \\
\hline $\begin{array}{l}\text { Constraints of } \\
\text { depending on the } \\
\text { charitable food } \\
\text { sector }\end{array}$ & $\begin{array}{l}\text { - Foods not always } \\
\text { sufficient or medically } \\
\text { appropriate } \\
\text { - Hard to stay 'on-diet' when } \\
\text { relying on food pantries } \\
\text { and soup kitchens }\end{array}$ & $\begin{array}{l}\text { 'I don't stay away from it because I'm not } \\
\text { supposed to be eating that or that, but I'm going } \\
\text { to eat it anyway, because I'm hungry. It's really } \\
\text { all that I have.' }\end{array}$ & $\begin{array}{l}\text { 1. Design comprehensive } \\
\text { nutrition standards for } \\
\text { charitable food sector }\end{array}$ \\
\hline
\end{tabular}

$25 \%$ by the end of the month compared with the beginning of the month, while no such pattern existed within higherincome patients ${ }^{(38)}$.

For households who are managing diet-related chronic conditions, the regular consumption of healthy diets high in fruits, vegetables and whole grains and low in added sugar, salt and fat is essential for positive disease outcomes. However, extensive prior literature around the differential cost of healthy and unhealthy foods supports the challenges of affordability our participants expressed. Energydense foods, such as those including refined grains, added sugars and fats, have been found to be less expensive than recommended, nutrient-dense foods including fresh fruits, vegetables and lean meats ${ }^{(39-42)}$. Furthermore, while several studies have shown that some nutrient-dense foods are available at lower price points, these items are not always socially acceptable or palatable to low-income shoppers ${ }^{(43,44)}$. In addition, studies have found that foods for specialized medical diets, such as gluten-free foods, are both less available and more expensive than their conventional alternatives $^{(45,46)}$. Along with the findings from our participants, these studies emphasize how SNAP households managing chronic illnesses are hard pressed to adhere to recommended dietary guidelines throughout the month 
and particularly in the final days of the benefit cycle. This challenge is heightened by the higher costs of healthy foods and specialty diet food items.

Given the disparities by income and race in chronic disease prevalence within the USA, as well as the higher mortality rates among SNAP participants for CVD and diabetes, critical attention to disease-specific diet quality within this population is essential. Recent literature has highlighted how important food is for health - a concept sometimes referred to as 'food is medicine' - including a recent study demonstrating that SNAP enrolment was associated with lower estimated annual health-care expenditures ${ }^{(47)}$. Several recent food provision interventions among populations with HIV and/or diabetes have found significant improvements in medication adherence, glycaemic control, fruit and vegetable intake and self-efficacy ${ }^{(48,49)}$. Additionally, studies evaluating healthy food subsidies or incentives within the SNAP population have shown significant increases in vegetable and fruit consumption ${ }^{(50,51)}$. Targeting improvements in chronic disease outcomes, a recent study using stochastic modelling showed that expanding a SNAP vegetable and fruit subsidy nationwide would be expected to reduce type 2 diabetes incidence by $1.7 \%$ and myocardial infarction by $1.4 \%{ }^{(52)}$. This model also predicted significant societal cost savings from long-term reductions in diabetes and CVD. This research suggests that subsidizing or incentivizing the purchase of certain disease-specific healthy foods (e.g. fruits, vegetables, low-sodium foods) may improve the chronic disease self-management and outcomes of SNAP participants.

Other policy recommendations to address the high cost of medically appropriate diets and end-of-month insufficiency, detailed in Table 3, include increasing the size of benefits and distributing SNAP benefits more frequently during the month. While increasing benefit size is a politically challenging proposition, evidence suggests that increasing benefit size could significantly reduce emergency department medical claims and Medicaid expenditures ${ }^{(53,54)}$, meaning this investment in food security could potentially both improve population health and reduce government medical spending.

\section{Formal assistance, individualized care and scalability}

As a coping strategy to fill in the gaps after benefits had run out, SNAP participants in our study turned to a constellation of other largely community-based resources, many of which, while instrumental in their food, financial and disease management assistance, had limitations of their own. The charitable resources on which participants relied (e.g. food pantries, soup kitchens) often could not provide adequate or appropriate foods for effective disease management. The low nutritional quality and insufficient supply of the foods described by our participants at many food assistance programmes aligns with findings from previous studies ${ }^{(55-59)}$. These perceived inadequacies resulted in many participants feeling that they could not rely on these resources to alleviate food insecurity or supply the necessary foods for their chronic disease management. Despite these noted limitations, it is remarkable that some food pantries have found innovative ways to address the myriad health needs of their clients, including offering products tailored to certain chronic diseases, using nutritional guidelines for stocking requirements, and providing health screenings and counselling $(49,60,61)$

That said, those households who did rely regularly on formal community assistance programmes generally expressed gratitude for the services they provided, even if the foods received were not always aligned with their particular needs. Most notably, the flexibility and individualized care of community-based resources were highly valued by participants, particularly in contrast to the rigidity of federal welfare programmes. The individualized care that participants described as instrumental in their survival home health aides tracking SNAP benefits, social workers putting their name on the waitlist for a food pantry reduced some of the ongoing stress and juggling of multiple priorities participants experienced. Ultimately, this care may have positive impacts on the SNAP cycle and chronic disease self-management.

These accounts of individualized care, however, point to a broader problem within our social safety net. The experiences of our study participants highlight the degree to which SNAP households with chronic diseases need help navigating not only food resource systems, but also health-care and social service systems. The US social service programmes - Medicaid, SNAP, Social Security Disability - are incredibly challenging to navigate ${ }^{(62,63)}$ and, in the case of the SNAP households in the present study, often required assistance from highly individualized formal support systems. This type of targeted and hightouch care has become necessary for the survival and well-being of many low-income Americans, particularly as income volatility has increased ${ }^{(64,65)}$ and the social safety net has been dismantled through funding cuts, punitive work requirements and political ill-will towards the poor $^{(66)}$. Not everyone has access to these highly individualized resources, however, and this model of care is not scalable or sustainable within our current political context. One strategy that can address these disparities in access to care, recommended by numerous American medical associations, is for medical professionals to screen for food insecurity in the clinical setting and work with patients and social workers to adjust the medical plan with food access in mind ${ }^{(67-69)}$. Another strategy to provide structural support for individuals with disabilities to reduce the burden of navigating the benefit system, could include reducing administrative hurdles for benefits application and recertification $^{(70)}$. 


\section{Study limitations}

The convenience sample located entirely within Philadelphia, which is a high-poverty urban area, is not generalizable for the national SNAP population, which includes large numbers of rural recipients ${ }^{(71)}$. Given the interview format of data collection and the sensitive nature of the topic matter, participants' responses may have been influenced by social desirability bias. Additionally, responses about chronic disease incidence and selfmanagement were self-reported. Future research with a larger and more representative SNAP population is needed to better understand the challenges and implications of chronic disease self-management among SNAP recipients.

\section{Conclusion}

The prevalence and severity of challenges managing dietrelated chronic diseases among SNAP participants demonstrated by our study draw attention to a critically understudied topic within the SNAP literature. Recent studies demonstrating the effectiveness of subsidizing certain foods on both healthy food consumption and chronic disease management suggest that evaluations of further interventions are warranted.

\section{Acknowledgements}

Acknowledgements: The authors wish to thank the participants for sharing their time and experiences. The authors would also like to acknowledge the following people for their contribution to this study: Taylor White-Welchon, Elizabeth Stulpin, Dr Virginia Stallings, Dr Terri Lipman and Dr Lisa Servon. Financial support: This work was supported by the University of Pennsylvania Leonard Davis Institute of Health Economics (M.O.); the University of Pennsylvania Graduate and Professional Student Assembly Provost Award for Interdisciplinary Innovation (M.O., E.W.K.); the National Institutes of Health, National Institute of Diabetes and Digestive and Kidney Diseases Pediatric Endocrine Fellowship Training in Diabetes Research (M.O.); and the Investment for the Future Initiative in Community Practices, University of Pennsylvania School of Nursing (C.C.C.). The sources of financial support had no role in the design, analysis or writing of this article. Conflict of interest: None. Authorship: E.W.K., M.O., C.C.C. and A.H. formulated the research questions and designed the study. E.W.K. collected and analysed the data and wrote the manuscript. M.O. collected data. R.D. analysed data. All authors edited and approved the manuscript. Ethics of buman subject participation: This study was conducted according to the guidelines laid down in the Declaration of Helsinki and all procedures involving human subjects were approved by the University of Pennsylvania and Children's
Hospital of Philadelphia Institutional Review Boards. Written informed consent was obtained from all subjects.

Author ORCIDs. (D) Eliza Whiteman Kinsey, 0000-00034972-431X. Roxanne Dupuis, 0000-0003-3161-6310.

\section{References}

1. Food and Agriculture Organization of the United Nations, International Fund for Agricultural Development, UNICEF et al. (2017) The State of Food Security and Nutrition in the World 2017. Rome: FAO; available at http://www.who. int/nutrition/publications/foodsecurity/state-food-securitynutrition-2017-inbrief-en.pdf?ua=1

2. Kharmats AY, Jones-Smith JC, Cheah YS et al. (2014) Relation between the Supplemental Nutritional Assistance Program cycle and dietary quality in low-income African Americans in Baltimore, Maryland. Am J Clin Nutr 99, 1006-1014.

3. Wilde PE \& Ranney CK (2000) The monthly food stamp cycle: shopping frequency and food intake decisions in an endogenous switching regression framework. Am J Agric Econ 82, 200-213.

4. Shapiro JM (2005) Is there a daily discount rate? Evidence from the food stamp nutrition cycle. J Public Econ 89, 303-325.

5. Hamrick KS \& Andrews M (2016) SNAP participants' eating patterns over the benefit month: a time use perspective. PLoS One 11, e0158422.

6. Whiteman ED, Chrisinger BW \& Hillier A (2018) Diet quality over the monthly Supplemental Nutrition Assistance Program cycle. Am J Prev Med 55, 205-212.

7. Sanjeevi N \& Freeland-Graves J (2018) Monthly variations in dietary intake of women participating in the Supplemental Nutrition Assistance Program. J Acad Nutr Diet 119, 261-271.

8. Silverman J, Krieger J, Kiefer M et al. (2015) The relationship between food insecurity and depression, diabetes distress and medication adherence among low-income patients with poorly-controlled diabetes. J Gen Intern Med 30, 1476-1480.

9. Lorig KR, Ritter P, Stewart AL et al. (2001) Chronic disease self-management program: 2-year health status and health care utilization outcomes. Med Care 39, 1217-1223.

10. Ory MG, Smith ML, Ahn S et al. (2014) National study of chronic disease self-management: age comparison of outcome findings. Health Educ Behav 41, 1 Suppl., 34S-42S.

11. Blackwell D, Lucas J \& Clarke T (2014) Summary health statistics for US adults: National Health Interview Survey, 2012. National Center for Health Statistics Vital Health Stat 10 issue $260,1-161$.

12. Tarasuk V, Mitchell A, McLaren L et al. (2013) Chronic physical and mental health conditions among adults may increase vulnerability to household food insecurity. J Nutr $\mathbf{1 4 3}$, 1785-1793.

13. Alley DE, Soldo BJ, Pagán JA et al. (2009) Material resources and population health: disadvantages in health care, housing, and food among adults over 50 years of age. $\mathrm{Am} \mathrm{J}$ Public Health 99, Suppl. 3, S693-S701.

14. Berkowitz SA, Berkowitz TSZ, Meigs JB et al. (2017) Trends in food insecurity for adults with cardiometabolic disease in the United States: 2005-2012. PLoS One 12, e0179172.

15. Seligman HK, Laraia BA \& Kushel MB (2010) Food insecurity is associated with chronic disease among low-income NHANES participants. J Nutr 140, 304-310.

16. Lyles CR, Schafer AL \& Seligman HK (2014) Income, food insecurity, and osteoporosis among older adults in the 2007-2008 National Health and Nutrition Examination 
Survey (NHANES). J Health Care Poor Underserved 25 , 1530-1541.

17. Seligman HK \& Schillinger D (2010) Hunger and socioeconomic disparities in chronic disease. N Engl J Med 363, 6-9.

18. Seligman HK, Bindman AB, Vittinghoff E et al. (2007) Food insecurity is associated with diabetes mellitus: results from the National Health Examination and Nutrition Examination Survey (NHANES) 1999-2002. J Gen Intern Med 22, 1018-1023.

19. Ford ES (2013) Food security and cardiovascular disease risk among adults in the United States: findings from the National Health and Nutrition Examination Survey, 2003-2008. Prev Chronic Dis 10, E202.

20. Berkowitz SA, Baggett TP, Wexler DJ et al. (2013) Food insecurity and metabolic control among US adults with diabetes. Diabetes Care 36, 3093-3099.

21. Wang EA, Zhu GA, Evans L et al. (2013) A pilot study examining food insecurity and HIV risk behaviors among individuals recently released from prison. AIDS Educ Prev 25, 112-123.

22. Cluver L, Orkin M, Boyes M et al. (2011) Transactional sex amongst AIDS-orphaned and AIDS-affected adolescents predicted by abuse and extreme poverty. J Acquir Immune Defic Syndr 58, 336-343.

23. Tsai AC, Hung KJ \& Weiser SD (2012) Is food insecurity associated with HIV risk? Cross-sectional evidence from sexually active women in Brazil. PLoS Med $\mathbf{9}$, e1001203.

24. Whittle HJ, Palar K, Seligman HK et al. (2016) How food insecurity contributes to poor HIV health outcomes: qualitative evidence from the San Francisco Bay Area. Soc Sci Med 170, 228-236.

25. Wang EA \& Wildeman C (2011) Studying health disparities by including incarcerated and formerly incarcerated individuals. JAMA 305, 1708-1709.

26. Weiser SD, Yuan C, Guzman D et al. (2013) Food insecurity and HIV clinical outcomes in a longitudinal study of urban homeless and marginally housed HIV-infected individuals. AIDS 27, 2953-2958.

27. Berkowitz SA, Seligman HK \& Choudhry NK (2014) Treat or eat: food insecurity, cost-related medication underuse, and unmet needs. Am J Med 127, 303-310.e3.

28. Conrad Z, Rehm CD, Wilde P et al. (2017) Cardiometabolic mortality by Supplemental Nutrition Assistance Program participation and eligibility in the United States. Am J Public Health 107, 466-474.

29. Andreyeva T, Tripp AS \& Schwartz MB (2015) Dietary quality of Americans by Supplemental Nutrition Assistance Program participation status: a systematic review. Am J Prev Med 49, 594-604.

30. US Department of Agriculture, Economic Research Service (2017) Food Insecurity in the US: Measurement. https:// www.ers.usda.gov/topics/food-nutrition-assistance/foodsecurity-in-the-us/measurement/ (accessed November 2017).

31. Harris PA, Taylor R, Thielke $\mathrm{R}$ et al. (2009) Research electronic data capture (REDCap) - a metadata-driven methodology and workflow process for providing translational research informatics support. J Biomed Inform 42, $377-381$.

32. US Department of Agriculture, Food and Nutrition Service, Office of Research Analysis (2013) SNAP Food Security In-Depth Interview Study. Alexandria, VA: US Department of Agriculture, Food and Nutrition Service.

33. Giacomini MK \& Cook DJ (2000) Users' guides to the medical literature: XXIII. Qualitative research in health care B. What are the results and how do they help me care for my patients? Evidence-Based Medicine Working Group. JAMA 284, 478-482.

34. Giacomini MK \& Cook DJ (2000) Users' guides to the medical literature: XXIII. Qualitative research in health care A. Are the results of the study valid? Evidence-Based Medicine Working Group. JAMA 284, 357-462.

35. Pope C \& Mays N (1999) Qualitative Research in Health Care. London: BMJ Books.

36. Pope C, Ziebland S \& Mays N (2007) Analysing qualitative data. In Qualitative Research in Health Care, 3rd ed., pp. 63-81 [C Pope and N Mays, editors]. Oxford: Wiley-Blackwell.

37. Hastings J \& Washington E (2010) The first of the month effect: consumer behavior and store responses. Am Econ J Econ Policy 2, 142-162.

38. Seligman HK, Bolger AF, Guzman D et al. (2014) Exhaustion of food budgets at month's end and hospital admissions for hypoglycemia. Health Aff (Millwood) 33, 116-123.

39. Drewnowski A (2004) Obesity and the food environment: dietary energy density and diet costs. Am J Prev Med 27, 3 Suppl., 154-162.

40. Drewnowski A \& Specter SE (2004) Poverty and obesity: the role of energy density and energy costs. Am J Clin Nutr 79, 6-16.

41. Drewnowski A \& Darmon N (2005) Food choices and diet costs: an economic analysis. J Nutr 135, 900-904.

42. Rao M, Afshin A, Singh G et al. (2013) Do healthier foods and diet patterns cost more than less healthy options? A systematic review and meta-analysis. BMJ Open 3, e004277.

43. Darmon N \& Drewnowski A (2015) Contribution of food prices and diet cost to socioeconomic disparities in diet quality and health: a systematic review and analysis. Nutr Rev 73, 643-660.

44. Maillot M, Darmon N \& Drewnowski A (2010) Are the lowestcost healthful food plans culturally and socially acceptable? Public Health Nutr 13, 1178-1185.

45. Lee AR, Ng DL, Zivin J et al. (2007) Economic burden of a gluten-free diet. J Hum Nutr Diet 20, 423-430.

46. Singh J \& Whelan K (2011) Limited availability and higher cost of gluten-free foods. J Hum Nutr Diet 24, 479-486.

47. Berkowitz SA, Seligman HK, Rigdon J et al. (2017) Supplemental Nutrition Assistance Program (SNAP) participation and health care expenditures among low-income adults. JAMA Intern Med 177, 1642-1649.

48. Palar K, Napoles T, Hufstedler LL et al. (2017) Comprehensive and medically appropriate food support is associated with improved HIV and diabetes health.J Urban Health 94, 87-99.

49. Seligman HK, Lyles C, Marshall MB et al. (2015) A pilot food bank intervention featuring diabetes-appropriate food improved glycemic control among clients in three states. Health Aff (Millwood) 34, 1956-1963.

50. Bartlett S, Klerman J, Olsho L et al. (2014) Evaluation of the Healthy Incentives Pilot (HIP): Final Report. Prepared by Abt Associates for US Department of Agriculture, Food and Nutrition Service. https://fns-prod.azureedge.net/sites/ default/files/ops/HIP-Final.pdf (accessed April 2019).

51. Harnack L, Oakes M, Elbel B et al. (2016) Effects of subsidies and prohibitions on nutrition in a food benefit program: a randomized clinical trial. JAMA Intern Med 176, $1610-1618$

52. Choi SE, Seligman H \& Basu S (2017) Cost effectiveness of subsidizing fruit and vegetable purchases through the Supplemental Nutrition Assistance Program. Am J Prev Med 52, e147-e155.

53. Ojinnaka CO \& Heflin C (2018) Supplemental Nutrition Assistance Program size and timing and hypertension-related emergency department claims among Medicaid enrollees. J Am Soc Hypertens 12, e27-e34.

54. Sonik RA (2018) Inpatient Medicaid usage and expenditure patterns after changes in Supplemental Nutrition Assistance Program benefit levels. Prev Chronic Dis 15, E120.

55. Poppendieck J (1999) Sweet Charity?: Emergency Food and the End of Entitlement. New York: Penguin Group. 
Chronic disease management in the SNAP cycle

2259

56. Grannon KY, Hoolihan C, Wang Q et al. (2016) Comparing the application of the Healthy Eating Index-2005 and the Healthy Eating Index-2010 in the food shelf setting. J Hunger Environ Nutr 12, 112-122.

57. Jessri M, Abed A, Wong A et al. (2014) Nutritional quality and price of food hampers distributed by a campus food bank: a Canadian experience. J Health Popul Nutr 32, 287-300.

58. Duffy P, Zizza C, Jacoby J et al. (2009) Diet quality is low among female food pantry clients in eastern Alabama. J Nut Educ Behave 41, 414-419.

59. Akobundu UO, Cohen NL, taus MJ et al. (2004) Vitamins A and $\mathrm{C}$, calcium, fruit, and dairy products are limited in food pantries. J Am Diet Assoc 104, 811-813.

60. Martin KS, Wu R, Wolff M et al. (2013) A novel food pantry program: food security, self-sufficiency, and diet-quality outcomes. Am J Prev Med 45, 569-575.

61. Food Equality Initiative (2019) Homepage. https://food equalityinitiative.org/ (accessed January 2019).

62. Magasi S (2012) Negotiating the social service systems: a vital yet frequently invisible occupation. OTJR (Thorofare NJ) $\mathbf{3 2}$, issue 1, S25-S33.

63. Sizer A (2007) Public health insurance, program take-up, and child health. Rev Econ Stat 89, 400-415.
64. Hacker JS \& Jacobs E (2008) The rising instability of American family incomes, 1969-2004: evidence from the Panel Study of Income Dynamics. http://www.epi.org/publication/bp213/ (accessed November 2016).

65. Ziliak JP, Hardy B \& Bollinger C (2011) Earnings volatility in America: evidence from matched CPS. Labour Econ 18, 742-754.

66. Tach L \& Eden K (2017) The social safety net after welfare reform: recent developments and consequences for household dynamics. Ann Rev Sociol 43, 541-561.

67. Smith S, Malinak D, Chang J et al. (2017) Addressing food insecurity in family medicine and medical education. Fam Med 49, 765-771.

68. Patil SP, Craven K \& Kolas K (2018) Food insecurity: how you can help your patients. Am Fam Physician 98, 143-145.

69. Council on Community Pediatrics, Committee on Nutrition (2015) Promoting food security for all children. Pediatrics 136, e1431-e1438.

70. Mullainathan S \& Shafir E (2013) Scarcity: Why Having Too Little Means So Much. New York: Picador.

71. Lauffer S (2017) Characteristics of Supplemental Nutrition Assistance Program Households: Fiscal Year 2016. Alexandria, VA: US Department of Agriculture, Food and Nutrition Service, Office of Policy Support.

https://doi.org/|0.1017/S1368980019001071 Published online by Cambridge University Press 